and some present and projected impacts upon librarianship of on-line methods of reference service.

Part II (the remaining hundred pages of text) reproduces the laboratory exercises used in teaching practical search skills. A feature of particular interest to the teacher or librarian specializing in this area is that five systems are covered: As long as this reflects classroom exposure to multiple systems (as it apparently does here) and not the substitution of comparative-theoretic study for actual hands-on training, it is to be welcomed, for it both widens the knowledge and sharpens the discrimination of the student.

The systems are discussed in two groups: first, Lockheed's DIALOG and the European Space Agency's RECON-these are similar in being direct descendants of the original Lockheed RECON system; and, second, SDC's ORBIT, NLM's ELHILL, and the British Library's recent crucial effort, BLAISE (British Library Automated Information Service). However, all the BLAISE examples are drawn from its first on-line operation, i.e., MEDLINE using ELHILL III C and, apart from the log-on

\section{Some Things}

\section{You Can}

\section{Count On....}

- Inadequate book budget

- Priority orders

- Books wanted "Yesterday"

- THE BOOK HOUSE

- Call 517-849-2117 Collect -

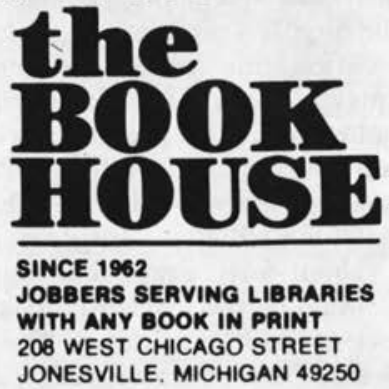

procedures, are combined with the NLM MEDLINE examples.

The book contains a fair number of incomplete or misleading statements, especially in Part I. "Display terminals normally operate at $30 \mathrm{cps}$ " (p.16). "The costs involved in on-line access to bibliographical data-bases can be divided into the capital expenditure of acquiring the terminal, and the actual costs of searching" (p.30). There are also frequent careless errors with reference to U.S. agency, place, and personal names, and the authors overindulge that fatal tendency to present sample searches on the topic of computerized information retrieval systems. Somehow, the points always come across more clearly when they use examples like "Shrimp Fishing" or "Hypoglycemia" or "Disadvantaged Youth."

I doubt that this work could serve its primary purpose, i.e., as a textbook, in the U.S., but it may be of interest to specialists in, and teachers of, on-line systems for its comparative approach.-Peter G. Watson, California State University, Chico.

Running Out of Space-What Are the Alternatives? Gloria Novak, editor. Proceedings of the Preconference, June 1975, San Francisco. Sponsored by the Buildings for College and University Libraries Committee, Buildings and Equipment Section of the Library Administration Division. Chicago: American Library Assn., 1978. 160p. \$14. LC 781796. ISBN 0-8389-3215-0.

Conference proceedings, unless they are drastically edited for publication in book form, usually come out something like minutes of a meeting - not very good reading. This volume is no exception, especially in records of discussion at the end of each series of speakers. Although the presentations by the speakers are reasonably well organized, discussions are often recorded as disjointed comments made by a mixture of program speakers and conference attendees. The latter are sometimes identified only by surname.

Looking at the substance rather than the form of this volume, the following alternatives to running out of space are examined: (1) Book storage (at Harvard and University of Washington); (2) microforms; (3) compact 
shelving (by Frazer Poole) and an automated retrieval system (compact storage a la carte by Harold Roth); (4) regional cooperation (the Research Libraries Group, which then included Harvard); (5) new buildings, additions, and renovations (Metcalf on renovation, going underground at the University of British Columbia, and abandoning the tower at Texas).

The volume ends with a view from the outside given by Robert Propst of Herman Miller Research Corporation and Doug Englebart, director of the Augmentation Research Center. The latter's presentation is particularly noteworthy as he deals with "similitude" and concludes that, "The steady increase in scale of total quantity, rate of production and access requests for our recorded knowledge is bound to hit limits where the current form of our libraries simply cannot function." The library as a document warehouse is doomed. The future library will be less a repository and more a service agency providing access to information. The implications for space problems are obvious.

These proceedings, published in 1978, record a conference held in June 1975. One wonders why the three-year gap before publication. A number of developments related to some of the discussions of specific facility planning in this volume are noted here to serve as an update: (1) The partially under-the-Yard Pusey Library at Harvard has been occupied. (2) Mr. Skipper's thoughtful presentation of the Research Libraries Group goals and strategy must be tempered by the recent pulling back of Harvard as the biggest of the Big Four from this regional cooperative, as well as by potential further division as a result of adopting BALLOTS. Regional cooperation has many problems and is not seen as a significant alternative to running out of space. (3) The third largest academic library building in the United States, the University of Texas at Austin Perry-Castañeda Library has opened with a capacity for more than three million volumes and 3,200 user stations in its over 500,000 gross square feet. (4) Harold Roth's truly automated retrieval system (ARS) at the Nassau County Research Library never made it past the planning stage. ARS, the new building it was to be housed in, and finally the research library itself have fallen victim to withdrawal of funds. It does cost hard-to-find money to save space, to cooperate, and to build new buildings.

Some startling and important facts regarding the academic library space problem come to light in this volume. For instance, each of the four libraries of the Research Libraries Group must find two to three linear miles of shelving to accommodate each year's acquisitions. Also, the heavy expense of a volume-by-volume selection process for a "lesser used" storage collection, followed by the modification of catalog records, may exceed the value of the space saved.

The conference covered a number of alternatives and was limited primarily to the problems of book space rather than user, staff, or other library space. Metcalf points out that even Harvard, with its $10,000,000$ volumes, uses more space for readers and services and nonassignable purposes than it does for books.

These proceedings could have been enhanced by floor layouts, sketches, and pictures of specific buildings described. Visuals are usually part of such conferences.

Although there is no index or bibliography, this paperbound $\$ 14$ volume has some helpful and a little new material for those facing book space problems. One must conclude, however, that it would have been more interesting to hear these papers and discussions in person at the conference than to read them now in the published proceedings.-Selby U. Gration, State University of New York, College at Cortland.

\section{Woodward, A. M. Factors Affecting the} Renewal of Periodical Subscriptions. A Study of Decision-Making in Libraries with Special Reference to Economics and Inter-Library Lending. London: Aslib, 1978. 114p. \$25.20 North America; $\$ 21$ to Aslib members. $£ 8.40 \mathrm{UK}$; $£ 7$ to Aslib members.

The reasons why librarians decided to purchase, to cut some, or to cancel particular periodicals provide the material for this independent study conducted by Woodward at the Aslib Research and Development Department. The British Library Lending 